\title{
"The role of high-yield bonds in strategic asset allocation over the Great Recession"
}

\begin{tabular}{|c|c|}
\hline AUTHORS & $\begin{array}{l}\text { Georgios Menounos } \\
\text { Constantinos Alexiou (D https://orcid.org/0000-0002-9481-3066 } \\
\text { Sofoklis Vogiazas (D https://orcid.org/0000-0001-6141-3173 }\end{array}$ \\
\hline ARTICLE INFO & $\begin{array}{l}\text { Georgios Menounos, Constantinos Alexiou and Sofoklis Vogiazas (2017). The } \\
\text { role of high-yield bonds in strategic asset allocation over the Great Recession. } \\
\text { Investment Management and Financial Innovations, 14(3), 270-279. } \\
\text { doi:10.21511/imfi.14(3-1).2017.11 }\end{array}$ \\
\hline DOI & http://dx.doi.org/10.21511/imfi.14(3-1).2017.11 \\
\hline RELEASED ON & Monday, 13 November 2017 \\
\hline RECEIVED ON & Friday, 04 August 2017 \\
\hline ACCEPTED ON & Tuesday, 03 October 2017 \\
\hline LICENSE & $\begin{array}{l}(c) \text { Er-No } \\
\text { This work is licensed under a Creative Commons Attribution-NonCommercial } 4.0 \\
\text { International License }\end{array}$ \\
\hline JOURNAL & "Investment Management and Financial Innovations" \\
\hline ISSN PRINT & $1810-4967$ \\
\hline ISSN ONLINE & $1812-9358$ \\
\hline PUBLISHER & LLC "Consulting Publishing Company "Business Perspectives" \\
\hline FOUNDER & LLC "Consulting Publishing Company "Business Perspectives" \\
\hline
\end{tabular}

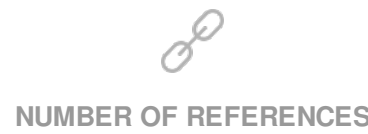

30
NUMBER OF FIGURES

1

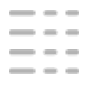

NUMBER OF TABLES

1

(C) The author(s) 2023. This publication is an open access article. 


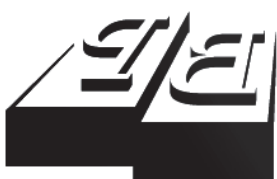

BUSINESS PERSPECTIVES

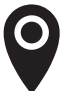

LLC "CPC "Business Perspectives" Hryhorii Skovoroda lane, 10, Sumy, 40022, Ukraine

www.businessperspectives.org

Received on: $4^{\text {th }}$ of August, 2017 Accepted on: $3^{\text {th }}$ of October, 2017

(C) Georgios Menounos, Constantinos Alexiou, Sofoklis Vogiazas, 2017

Georgios Menounos, Bank of Piraeus, Athens, Greece.

Constantinos Alexiou, Cranfield University, UK; Aristotle University of Thessaloniki, Greece.

Sofoklis Vogiazas, Black Sea Trade and Development Bank, Thessaloniki, Greece.

\section{(ㄷ)(1) $(8)$}

This is an Open Access article, distributed under the terms of the Creative Commons Attribution-NonCommercial 4.0 International license, which permits re-use, distribution, and reproduction, provided the materials aren't used for commercial purposes and the original work is properly cited.

\title{
THE ROLE OF HIGH-YIELD BONDS IN STRATEGIC ASSET ALLOCATION OVER THE GREAT RECESSION
}

\begin{abstract}
By utilizing a modified version of the Black-Litterman model, the authors explore the asset allocation to high-yield bonds based on an investor's risk profile. In so doing, the researchers use US data on high-yield bonds and over the period 2007-2013. The key finding relates to the strategic asset allocation to high-yield bonds in a simulated global market portfolio depending on an investor's risk tolerance. In particular, the share of high-yield bonds does not exceed $4.15 \%$ of total assets in a global market portfolio over the period 2007-2013, whilst the allocation remains relatively stable and small on a risk-adjusted basis, irrespective of an investor's risk profile or the phase of the business cycle. In simple terms, the results suggest that high-yield bonds do not seem to merit a favorable treatment in the asset allocation process relative to other financial instruments in a global market portfolio.
\end{abstract}

\section{Keywords Black-Litterman model, high-yield bonds, asset} allocation, global financial crisis

\section{JEL Classification $\quad \mathrm{C} 10, \mathrm{C} 61, \mathrm{G} 1$}

\section{INTRODUCTION}

Even though portfolio diversification is an effective way to minimize risk, correlation patterns of the securities' returns incorporated in a portfolio can produce unfavorable outcomes.

In the aftermath of the global financial crisis, portfolio diversification has transpired to be a strategy with minimal benefits for potential investors, as all major global equity indices were adversely affected. The lesson that we can learn from the recent global economic shock is of great significance in that portfolio diversification does not necessarily provide the same level of risk when the market is severely compromized. As a matter of fact, in severe economic recessions, the entire diversification process may be an illusion.

In this paper, we use historical return data from a set of indices that track the US equity and bond markets. By using the Black-Litterman model (Black \& Litterman, 1992) for twenty-five different asset classes that simulate the global market portfolio in the period 2007-2013 and broadly comprises both phases of the business cycle, we evaluate the extent to which investors' portfolios should be allocated to high-yield bonds based on their risk tolerance.

The rest of the paper is organized as follows: Section 1 touches on the respective literature, whilst section 2 elaborates on the data and methodological framework adopted in the empirical investigation. Section 3 discusses the results of our analysis, whilst final section provides some concluding remarks. 


\section{LITERATURE REVIEW}

High-yield bonds are thought of as a hybrid between investment-grade corporate debt and equity securities. Typically, the volatile price of high-yield bonds is less influenced by interest rate changes than investment grade ones, and they show high correlation with movements in equity markets. Shiller and Beltratti (1992) find a strong correlation between changes in stock prices and long-term bond yields, whilst Campbell and Ammer (1993) verify a low one. More recent studies claim that the correlation between stocks and bonds presents notable time variation (Gulko, 2002; Jones \& Wilson, 2004; Cappiello et al., 2006). According to the IMF (2015), the level of global asset market correlation has jumped upwards to around $80 \%$ in the post-crisis period (2008-2009). Between 1997 and 2007, the level of correlation between the major asset classes was around 45\%, roughly in line with historic norms. Despite the fact that historically, a crash is invariably accompanied by high correlations as panic drives the markets, in the post-crisis period apart from the soaring levels of asset price, the extant correlations remained high, at about $70 \%$, well above the pre-crisis level, suggesting that the global asset management industry is highly interconnected. As a consequence, there was little room for investors to diversify their portfolios.

The modern analysis on corporate debt has been initiated by Black and Scholes (1973) and Merton (1974). Merton (1974) points out that the holders of risky corporate bonds can be thought of as owners of riskless bonds who have issued put options to the firm's equity. When volatility increases, the put options increase in value, benefiting equity holders at the expense of bondholders. Bookstaber and Jacob (1986) found that as the quality of long-term corporate bonds declines, the correlation of their returns with the returns of treasury bonds decreases. At the same time, the correlation of corporate bonds with common stock returns increases. Similar findings are provided by Blume and Keim (1987) in their investigation of the risk-return features of junk bonds. Ramaswami (1991) provides evidence that the variance of noninvestment-grade bond returns is more influenced by sector-industry and firm-specific factors compared to investment-grade bonds.
Also, Regan (1990) by factoring in his analysis the business cycle phases, hints that the performance of junk bonds and those of low-quality stocks tend to reflect the riskiness of the particular individual companies rather than swings in the capital market.

Blume and Keim (1987) argue that noninvestment-grade bond returns exceed investmentgrade bond returns, but remain inferior to stock returns. Equally, the authors demonstrate that the volatility of equity returns is higher than that of both high-yield bond and investment-grade bond returns, perhaps because noninvestment-grade bond prices do not adjust to new information as rapidly as stock and investment-grade bond prices do. Similarly, Altman and Heine (1990) found that junk bonds offer superior returns to investment-grade and treasury bonds, having roughly the same standard deviation in their returns with them. Additionally, Altman and Heine (1990) argue that noninvestment-grade bonds outperform equities, even though stock returns present greater volatility than junk bond returns. Regan (1990) confirms that high-yield bonds outperform investment-grade bonds during economic expansions, but not during contraction periods when noninvestment-grade bond returns trail investment-grade bond returns.

Briere and Szafarz (2008) construct a crisis-proof portfolio by building a portfolio that exhibits the lowest volatility ratio between economic expansion and contraction periods. Overall, Briere and Szafarz (2008) found that junk bond returns are inferior to investment-grade bond returns in the long run and evidence that the standard deviation of high-yield bond returns is lower than the standard deviation of investment-grade bond returns in the long-term horizon. Zivney et al. (1993) argue that studies dated back to 1990 have failed to recognize the largest two constituents of volatility of fixed-income security returns: the capital gains or losses, resulting from changes in interest rates, and the reinvestment rate of coupons that are received at the current level of return, which may differ substantially from the promised yield to maturity. In contrast, the academic papers that are dated back to 1991 or later have controlled for these factors, still, they contained other methodological drawbacks. 
Manzi and Rayome (2016), who explore the investment performance of high-yield bonds and emerging market stocks, found that noninvestment-grade bond returns are superior to equity returns, while their standard deviation is lower than the standard deviation of stock returns. Contrary to the previous studies, Reilly et al. (2009) found that the standard deviation of noninvestment-grade bond returns is more than double the standard deviation of investment-grade bond returns, while high-yield bond and investment-grade bond returns are approximately the same. The authors argue also that the standard deviation of noninvestment-grade bond returns is almost the same with the standard deviation of investment-grade bond returns throughout periods when the level of the economic activity follows an uptrend, but it becomes three times bigger than it during periods when the level of the economic activity follows a downtrend, reaching the standard deviation of stock returns. Li et al. (2014) extend the literature on the performance of high yield relative to investment-grade bonds. By assuming that returns are normally distributed, the high-yield bonds exhibit superior returns relative to investment grade ones.

\section{The role of high-yield bonds in investing and the portfolio allocation process}

The investment-allocation research area was heavily influenced by Markowitz (1952) work that is considered the foundation of the modern portfolio theory. Although the mean-variance optimization (MVO) as developed by Markowitz (1952) constitutes a significant theoretical breakthrough, its application can be problematic as the expected returns cannot be easily estimated in a reasonable way. This limitation was overcome by Black and Litterman (1992) who combine the MVO with the Capital Asset Pricing Model (CAPM). Among other favorable aspects, the Black-Litterman model eliminates the problem of highly concentrated portfolios in a handful of assets. Brinson et al. (1986), Brinson et al. (1991) and Ibbotson and Kaplan (2000) highlight the importance of strategic asset allocation as key on the investment performance.
In general, researchers have not dealt extensively with noninvestment-grade bonds with respect to investment and portfolio management issues. Amongst others, Blume and Hein (1987), Kihn (1994), Reilly et al. (2009) and Manzi and Rayome (2016) argue that junk bonds can be regarded as sound investment vehicles as they promise enhanced returns and diversification benefits for investment-grade bond and equity investors. Kihn (1994) adds that periods of economic contraction contribute to the reduction in the volatility of noninvestment-grade bond returns in the long run, whilst Domian and Reichenstein (2008) argue that high-yield bond returns are not tax-efficient. Thus, individual investors should consider maintaining non investment-grade bonds in their portfolios. Fjelstad et al. (2005) argue that investors with low equity exposure can achieve meaningful portfolio returns through high-yield bonds. The authors show that high-yield bonds should not be regarded as a separate sub-asset class in the asset allocation process. In this context, Trainor Jr. and Wolfe (2006) point out the need for applying exact percentages instead of vague guesstimates regarding the extent to which noninvestmentgrade bonds should be included in investors' portfolios. Using the Black-Litterman model, Trainor Jr. and Wolfe (2006) found that the corresponding percentages decline significantly and are dependent on the spread of high-yield bond returns over investment-grade bond returns.

Briere and Szafarz (2008) stressed the flight-toquality effect, in which the volatility of returns for any security mounts over phases of the cycle. As a result, a bond portfolio that includes high-yield bonds of around $4.22 \%$ of total composition can with stand periods of downturn relatively better than a "safe" portfolio. Bekkers et al. (2009) conclude that high-yield bonds add value to a portfolio of ten different asset and sub-asset classes, applying three different research methodologies.

In so far, the literature suggests an equity-like component in high-yield bonds along with their prominent role in the portfolio construction process, and ultimately the investment decision. However, the literature does not provide an unambiguous position as to the extent investors should include in their portfolios high-yield bonds on the basis of their risk tolerance. 


\section{EMPIRICAL INVESTIGATION}

In demarcating the business cycle phases, we utilize data from the National Bureau of Economic Research (NBER, 2010). In particular, the most recent economic contraction is envisaged to be the period in December 2007 to June 2009, whilst the upswing of the cycle started in July 2009, i.e., following immediately after the Great Recession. The selection of the data frequency plays a key role in order to separate critical information from noise. Choosing a frequency lower than monthly could undermine the empirical analysis due to volatile fluctuations evident on higher frequency data. We opted for monthly data frequency, in our attempt to eliminate fluctuations. We also use indices, i.e., portfolios of securities, which represent specific markets, hence, tracking their overall performance and measuring their aggregate changes with a good level of accuracy. Figure 1 maps out a selection of the key indices used in our study. Table A1 (Appendix) presents the entire spectrum of the indices used, as well as the relevant sources, while Table A2 (Appendix) presents the correlation matrix of the indices used in our study.

Apart from the excess rate of return, we have also computed the nominal risk-free rate of return by focusing on the part of returns that are associated with the embedded risk in the sub-asset classes under study. The most widely quoted benchmark of the nominal risk-free rate of return is the three-month US Dollar (USD) London Interbank Offered Rate (LIBOR). Once the annual threemonth USD LIBOR at the end of each month are collected from Bloomberg Professional Services, we then proceed with the computation of the monthly three-month USD LIBOR at the end of each month.

Realistically, private investors can not include in their portfolios all assets that form the global market portfolio. But they can invest in a broad range of sub-asset classes in order to maintain a portfolio that replicates closely the global market portfolio. According to Maginn et al. (2007), the selection criteria of the sub-asset classes for this purpose should be homogenous, diversifying and non-overlapping. Furthermore, the total market capitalization of the particular sub-asset classes should make up the biggest possible fraction of the overall investors' wealth, while each sub-asset class should carry the capacity to absorb a considerable portion of a potential investor's capital (Maginn et al., 2007). The indices that meet the selection criteria, as well as mirror the global market portfolio are depicted in Table A1 (Appendix).

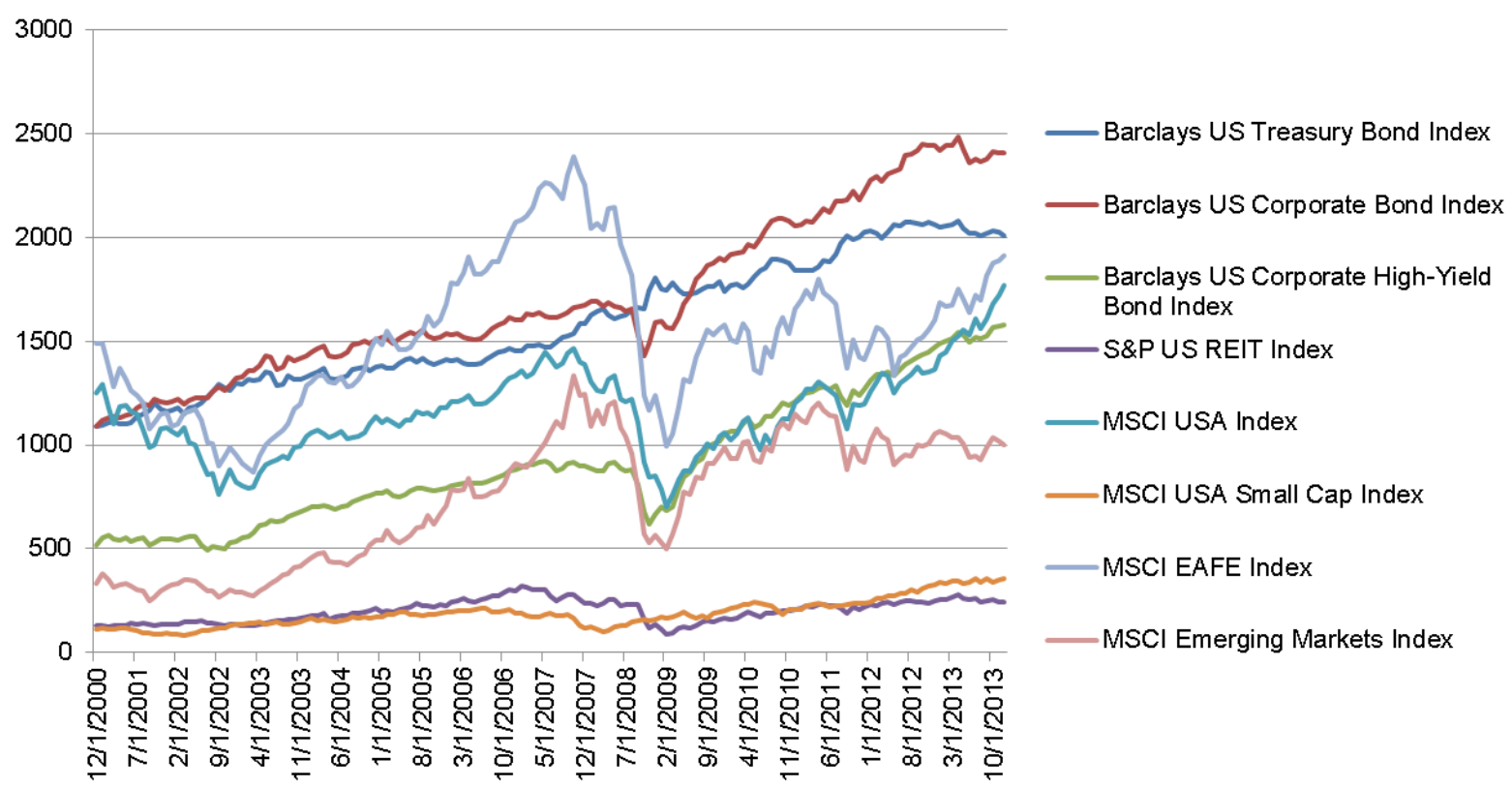

Figure 1. Key indices used in the study for the period 2000-2013 
Portfolio optimization constitutes a key operation of the investment management process, determining the weights of the various sub-asset classes in investors' portfolios in such a way as to construct optimal portfolios that offer investors the highest expected rate of return, according to their risk tolerance. One of the parameters of major importance for the successful implementation of the portfolio optimization process is the asset allocation strategy.

Risk tolerance is unique for each investor and constitutes a consequential parameter of the investment and portfolio management process. More specifically, it indicates the degree of volatility of investment returns that an investor can accept, based on their individual characteristics such as family obligations, age, net worth, cash reserves, income expectation sand insurance coverage.

The Black-Litterman model has gained momentum since its publication in 1992, while it remains a popular portfolio optimization model, thanks to its efficiency and ability to construct optimal portfolios for investors with different risk tolerance profiles by implementing the strategic asset allocation strategy.

Even though the bulk of the studies in this area suggest that high-yield bonds play a critical role in the investment and portfolio management process. However, most studies do not provide clear evidence on the extent to which high-yield should be included in investors' portfolios, according to investors' personal risk tolerance. We deal with this ambiguity by looking into the extent to which investors' portfolios are allocated to high-yield bonds, in accordance with the investors' personal risk tolerance, during the two phases of the business cycle, the contraction and the expansion phase.

In so doing, a modified version of the BlackLitterman model is employed in order to construct a breadth of optimal portfolios that cover the entire range of different investors' risk tolerance profiles, determining the exact percentage of investors' portfolios allocation to high-yield bonds, according to investors' personal risk tolerance, over periods wherein the level of the economic activity follows an uptrend or a downtrend ${ }^{1}$.

Initially, the adjusted closing prices of all sampled indices at the end of each month are collected from Bloomberg Professional Services, excluding the financial data which are collected from the Barclays Guides \& Factsheets and Cambridge Associates Private Investment Benchmark ${ }^{2}$, respectively. The closing prices are adjusted for dividends and stocksplits. Subsequently, the monthly total returns of the particular indices at the end of each month are computed as follows:

$M T R_{j, m}=\left(A C P_{j, m}-A C P_{j, m-1}\right) / A C P_{j, m-1}$,

where $M T R_{j, m}$ is the rate of monthly total return of index $j$ at the end of month $m, A C P_{j, m}$ is the adjusted close price of index $j$ at the end of month $m, A C P_{j, m-1}$ is the adjusted close price of index $j$ at the end of month $m-1$.

We compute the monthly total returns at the end of each month in each quarter using the following formula:

$$
\operatorname{MTR}_{q 1, q 2, q 3}=\left(1+Q T R_{q}\right)^{1 / 3}-1,
$$

where $M T R_{q 1, q 2, q 3}$ is the rate of monthly total return of Cambridge Associates Global ex-US Private Equity \& Venture Capital Index at the end of month, $q 1, q 2$ and $q 3$ of quarter $q$ and $Q T R_{q}$ is the rate of quarterly total return of Cambridge Associates Global ex-US Private Equity \& Venture Capital Index at the end of quarter $q$.

The monthly excess returns over the nominal riskfree rate of return of all sampled indices at the end of each month are computed by subtracting the monthly three-month USD LIBOR from the monthly total returns of the particular indices at the end of each month.

Assuming that the aggregate market capitalization of all sampled indices equals to the overall

1 The modified version of the Black-Litterman model has been applied for twenty five different sub-asset classes and the entire process is conducted twice to capture the period of economic expansion and contraction. The programming code can be provided upon request for replication purposes.

2 Available at: https://www.cambridgeassociates.com/our-insights/our-insights-archive/?tab=benchmark 
market capitalization of the global market portfolio, the third research hypothesis requires computing the market weights of all sampled indices in the global market portfolio at the end of each month. It is, therefore, required sampling their corresponding market capitalization sat the end of each month. Given the lack of available data, we assume that the market weights of all sampled indices in the global market portfolio remain constant or, in other words, the market capitalizations of all sampled indices have been altered proportionally throughout the time span of our study. Consequently, the market capitalization of all sampled indices are collected at the end of the second quarter of 2016 using Bloomberg Professional Services, the Barclays Guides \& Factsheets and Cambridge Associates Private Investment Benchmarks. Next, the market capitalization of the global market portfolio is computed by summing the market capitalizations of all sampled indices. The weights of all sampled indices in the global market portfolio are computed by dividing their market capitalization by the market capitalization of the global market portfolio. The market capitalization and the respective market weight are presented in Table A1 (Appendix).

\section{ESTIMATION RESULTS AND DISCUSSION}

The modeling results on the composition of highyield bonds in an investor's optimal portfolio on the basis of their risk profile are summarized in Table 1.

The results suggest that high-yield bonds should constitute $3.81 \%, 3.72 \%, 4.15 \%, 4.04 \%$ and $4.02 \%$ of the total composition of the optimal portfolios of the different investors' risk tolerance profiles, moving from the risk-averse to the aggressive risk tolerance profile. For the economic expansion period, the risk compensation of the optimal portfoli- os for the different investors' risk tolerance profiles are $0.97 \%, 1.33 \%, 1.61 \%, 1.87 \%$ and $2.08 \%$, moving from the risk-averse to the "aggressive" risk profile. Evidently, moving from the risk-averse to the aggressive risk profile raises the compensation for the additional level of risk taken. In the economic contraction period, the risk compensation in the optimal portfolios of different investors' risk profile is as follows: $0.45 \%, 0.96 \%, 1.35 \%, 1.62 \%$ and $1.86 \%$, moving from the risk-averse towards the aggressive investor.

Our results validate the modified version of the Black-Litterman model. In particular, it is found that the allocation to high-yield bonds on the basis of investors' risk tolerance is quite similar throughout both phases of the business cycle. Furthermore, our results suggest that the allocation to high-yield bonds does not change significantly as we move from the risk-averse to the aggressive risk profile. Instead, there is some preliminary indication that the allocation may follow a random walk. The allocation's pattern can be attributed to the fact that in a well-diversified portfolio, the risk of each investor's portfolio does not depend on the individual risk of each individual asset that is included in it, but is subjected to the risk of the entire asset mix. The latter is substantiated by the fact that the share of high-yield bonds in a global market portfolio of any risk appetite and irrespective of the business cycle does not exceed $4.15 \%$ of total assets.

Our results are not aligned with the findings reported in several related studies. However, our results coincide to a considerable extent with Bekkers et al. (2009) who found that $3.2 \%$ to $6.6 \%$ of investors' portfolios should be allocated to junk bonds, employing the MVO combined with the optimal portfolio that was constructed to replicate the global market portfolio. Yet, when Bekkers et al. (2009) applied the aforementioned methodologies individually, they found that noninvest-

Table 1. Composition of high-yield bonds in an investor's optimal portfolio

\begin{tabular}{c|c|c|c|c}
\hline \multicolumn{1}{c}{ Risk profile } & Risk-averse & Conservative & Moderate & $\begin{array}{c}\text { Moderately } \\
\text { aggressive } \\
\text { Aggressive }\end{array}$ \\
\hline Expansion period & $3.81 \%$ & $3.72 \%$ & $4.15 \%$ & $4.04 \%$ \\
Contraction period & $4.09 \%$ & $3.94 \%$ & $3.78 \%$ & $4.02 \%$ \\
\hline
\end{tabular}


ment-grade bonds should constitute $0 \%-14 \%$ and $1.1 \%$ of the total composition of investors' portfolios, respectively. Similarly, Trainor Jr. and Wolfe (2006) found that $0 \%$ to $42 \%$ and $0 \%$ to $26 \%$ of investors' portfolios should be allocated to noninvestment bonds, employing the MVO and the Black-Litterman model, respectively. The differences observed between our results and previous studies can be reasonably explained by the timeframe used in our study which is broadly defined by changing correlations between the asset classes. The fundamental changes in the macroeconomic environment and the financial market dynamics do impact the investors' assessment of risk and the relationship between stocks and bonds (Andersson et al., 2008).

\section{CONCLUSION}

A variant of the Black-Litterman model has provided the platform upon which are fined/unique risk measure is devised and effectively used in the portfolio optimization process. We find that that the percentage that should be allocated to high-yield bonds in investment portfolios ranges between $3.72 \%$ to $4.15 \%$ over expansionary periods, and between $3.78 \%$ to $4.07 \%$ over contraction periods and depending on the investor's risk tolerance profile. In simple terms, our results suggest that high-yield bonds do not seem to merit a favorable treatment in the asset allocation process relative to other financial instruments in a global market portfolio.

In passing, it should be stressed that this study has been conducted on the assumption that investors' utility is consistent across all investors' wealth levels and remains constant throughout the entire investment horizon, even though the specific assumption does not hold in the real world of finance. In addition, in the empirical investigation we have not accounted for friction costs, which, undoubtedly, affect an investment strategy, as well as the portfolio allocation in the real world. Although, friction costs could add a great deal of complexity, their inclusion could not guarantee a meaningful contribution to the validity and reliability of our results.

\section{DISCLAIMER}

The views expressed in this paper are those of the authors and do not necessarily represent those of Cranfield University, the Black Sea Trade and Development Bank or Bank of Piraeus.

\section{REFERENCES}

1. Altman, E. I., \& Heine, M. L. (1990). How 1989 Changed the Hierarchy of Fixed Income Security Performance. Financial Analysts Journal, 46(3), 9-20.

2. Andersson, M., Krylova, E., \& Vähämaa, S. (2008). Why does the correlation between stock and bond returns vary over time? Applied Financial Economics, 18(2). http://dx.doi. org/10.1080/09603100601057854

3. Bekkers, N., Doeswijk, R. Q., \& Lam, T. W. (2009). Strategic Asset Allocation: Determining the Optimal Portfolio with Ten
Asset Classes. Journal of Wealth

Management, 12(3), 61-77.

Retrieved from https://ssrn.com/ abstract $=1498460$

4. Black, F., \& Litterman, R. (1992). Global Portfolio Optimization. Financial Analysts Journal, 48(5), 28-43. https://doi. org/10.2469/faj.v48.n5.28

5. Black, F., \& Scholes, M. (1973). The pricing of options and corporate liabilities. Political Economy, 81, 637-654. Retrieved from http://www.jstor.org/ stable/1831029
6. Blume, M. E., \& Keim, D. B. (1987). Lower-Grade Bonds: Their Risks and Returns. Financial Analysts Journal, 43(4), 26-33. https://doi.org/10.2469/faj.v43. $\mathrm{n} 4.26$

7. Bookstaber, R., \& Jacob, D. P. (1986). The Composite Hedge: Controlling the Credit Risk of High-Yield Bonds. Financial Analysts Journal, 42(2), 25-36. https://doi.org/10.2469/faj.v42. n2.25

8. Briere, M., \& Szafarz, A. (2008). Crisis-Robust Bond Portfolios. Journal of Fixed Income, 18(2), 
67-70. https://doi.org/10.3905/ jfi. 2008.712350

9. Brinson, G. P., Hood, L. R. \& Beebower, G. L. (1986). Determinants of Portfolio Performance. Financial Analysts Journal, 42(4), 39-44. https://doi. org/10.2469/faj.v51.n1.1869

10. Brinson, G. P., Singer, B. D. \& Beebower, G. L. (1991). Determinants of Portfolio Performance II: An Update. Financial Analysts Journal, 47(3), 40-48. https://doi.org/10.2469/faj. v47.n3.40

11. Campbell, J. Y., \& Ammer, J. (1993). What moves the stock and bond markets? A variance decomposition for longterm asset returns. Journal of Finance, 48, 3-37. https://doi. org/10.1111/j.1540-6261.1993. tb04700.x

12. Cappiello, L., Engle, R. F., \& Sheppard, K. (2006). Asymmetric Dynamics in the Correlations of Global Equity and Bond Returns. Journal of Financial Econometrics, 4(4), 537-572. https://doi. org/10.1093/jjfinec/nbl005

13. Domian, D. L., \& Reichenstein, W. (2008). Returns-Based Style Analysis of High-Yield Bonds. The Journal of Fixed Income, 17(4), 72-87. https://doi.org/10.3905/ jfi.2008.705543

14. Fjelstad, M., Fox, S., Paris, M., \& Ruff, M. (2005). The Role of HighYield and Emerging Market Debt for a US Investor. The Journal of Investing, 14(1), 52-62. https://doi. org/10.3905/joi.2005.479389

15. Gulko, L. (2002). Decoupling. Journal of Portfolio Management, 28(3), 59-67. https://doi. org/10.3905/jpm.2002.319843
16. Ibbotson, R. G., \& Kaplan, P. D. (2000). Does Asset Allocation Policy Explain 40, 90 or 100 Percent of Performance? Financial Analysts Journal, 56(1), 26-33. https://doi.org/10.2469/faj.v56. n1.2327

17. IMF (2015). Global Financial Stability Report, October 2015.

18. Jones, C., \& Wilson, J. (2004). The changing nature of stock and bond volatility. Financial Analysts Journal, 60, 100-113. https://doi. org/10.2469/faj.v60.n1.2595

19. Kihn, J. (1994). Unraveling the Low-Grade Bond Risk-Reward Puzzle. Financial Analysts Journal, 50(4), 32-42. https://doi. org/10.2469/faj.v50.n4.32

20. Maginn, J. L., Tuttle, D. L., McLeavey, D. W., \& Pinto, J. E. (2007). Managing Investment Portfolios: A Dynamic Process ( $3^{\text {rd }}$ ed.) USA: John Wiley \& Sons.

21. Manzi, J. A., \& Rayome, D. L. (2016). Investing in High RiskReturn Mutual Funds: Is it Worth the Risk? The Journal of Business \& Behavioral Sciences, 28(1), 90-97. Retrieved from https://www.nmu. edu/business/sites/DrupalBusiness/files/UserFiles/rayome $\% 20$ mutual\%20funds\%20journal.pdf

22. Markowitz, H. (1952). Portfolio Selection. The Journal of Finance, 7(1), 77-91. https:// doi.org/10.1111/j.17456622.2009.00240.x

23. Merton, R. C. (1974). On the Pricing of Corporate debt: The Risk Structure of Interest Rates. Journal of Finance, 29, 449-470. https://doi. org/10.1111/j.1540-6261.1974. tb03058.x
24. National Bureau of Economic Research (NBER) (2010). US Business Cycle Expansion and Contractions, December 2007 to December 2013, National Bureau of Economic Research (NBER) Data. Retrieved from http://www. nber.org/cycles/US_Business_Cycle_Expansions_and_Contractions_20120423.pdf

25. Ramaswami, M. (1991). Hedging the Equity Risk of High-Yield Bonds. Financial Analysts Journal, 47(5), 41-50. https://doi. org/10.2469/faj.v47.n5.41

26. Regan, P. J. (1990). Pension Fund Perspective: Junk Bonds Opportunity Knocks? Financial Analysts Journal, 46(3), 13-16.

27. Reilly, F. K., Wright, D. J., \& Gentry, J. A. (2009). Historic Changes in the High-Yield Bond Market. The Journal of Applied Corporate Finance, 21(3), 65-79. https://doi.org/10.1111/j.17456622.2009.00240.x

28. Shiller, R., \& Beltratti, A. (1992). Stock prices and bond yields. Can their comovements be explained in terms of present value models? Journal of Monetary Economics, 30(1), 25-26. https://doi. org/10.1016/0304-3932(92)90042-Z

29. Trainor Jr., W. J., \& Wolfe, E. R. (2006). High-Yield Bonds in Optimally Efficient Portfolios. The Journal of Personal Finance, 5(3), 76-86.

30. Zivney, T. L., Bertin, W. J., \& Torabzadeh, K. M. (1993). A Reexamination of the Investment Performance of Junk Bonds. Quarterly Journal of Business \& Economics, 32(2), 78-97. 


\section{APPENDIX}

Table A1. Market capitalization and market weight of the sampled indices Data sources: Bloomberg Professional Services, Barclays Guides and Factsheets, Cambridge Associates Private Investment

\begin{tabular}{|c|c|c|}
\hline Index & $\begin{array}{c}\text { Market } \\
\text { capitalization } \\
\text { (USD trn) }\end{array}$ & $\begin{array}{c}\text { Market } \\
\text { weight }(\%)\end{array}$ \\
\hline MSCI USA Index & 13.24 & 8.99 \\
\hline MSCI USA Small Cap Index & 2.86 & 1.94 \\
\hline MSCI EAFE Index & 9.74 & 6.61 \\
\hline MSCI EAFE Small Cap Index & 1.88 & 1.28 \\
\hline MSCI Emerging Markets Index & 3.05 & 2.07 \\
\hline MSCI Emerging Markets Small Cap Index & 0.61 & 0.41 \\
\hline MSCI USA High Dividend Yield Index & 5.89 & 4.00 \\
\hline MSCI EAFE High Dividend Yield Index & 1.97 & 1.34 \\
\hline MSCI Emerging Markets High Dividend Yield Index & 0.70 & 0.48 \\
\hline Barclays US Treasury Bond Index & 12.46 & 8.46 \\
\hline Barclays US Agency Debenture Index & 1.97 & 1.34 \\
\hline Barclays US Municipal Bond Index & 3.78 & 2.57 \\
\hline Barclays US Treasury Inflation Protected Securities (TIPS) Index & 1.08 & 0.73 \\
\hline Barclays US Mortgage Backed Securities (MBS) Index & 10.18 & 6.91 \\
\hline Barclays US Corporate Bond Index & 7.09 & 4.81 \\
\hline Barclays US Corporate High-Yield Bond Index & 1.34 & 0.91 \\
\hline Barclays Developed Markets ex-US Hard Currency Aggregate Bond Index & 41.23 & 28.00 \\
\hline Barclays Emerging Markets Hard Currency Aggregate Bond Index & 18.60 & 12.63 \\
\hline Bloomberg Precious Metals Index & 0.54 & 0.37 \\
\hline Bloomberg Commodity ex-Precious Metals Index & 2.13 & 1.45 \\
\hline S\&P US REIT Index & 0.84 & 0.57 \\
\hline S\&P Global ex-US REIT Index & 0.72 & 0.49 \\
\hline S\&P Listed Private Equity Index & 1.31 & 0.89 \\
\hline $\begin{array}{l}\text { Cambridge Associates Global ex-US Private Equity \& Venture Capital } \\
\text { Index }\end{array}$ & 1.11 & 0.75 \\
\hline Barclays U.S. Treasury Bill 1-3 Month Term Index (Cash Equivalent) & 2.93 & 1.99 \\
\hline Global Market Portfolio & 147.25 & 100.00 \\
\hline
\end{tabular}




\begin{tabular}{|c|c|c|c|c|c|c|c|c|c|c|c|c|c|c|c|c|c|c|c|c|c|c|c|c|}
\hline & 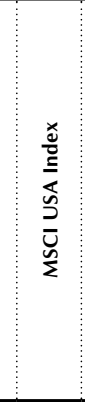 & 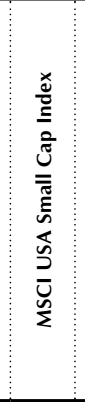 & 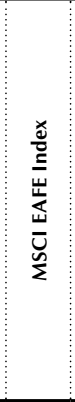 & 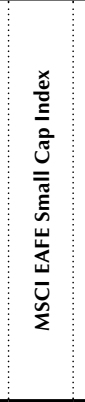 & 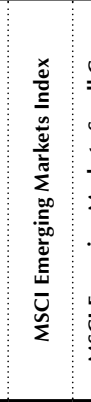 & 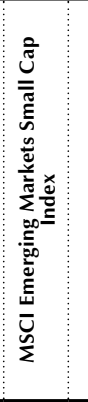 & 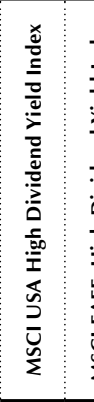 & 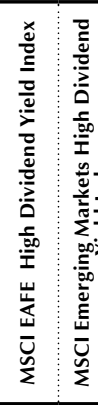 & 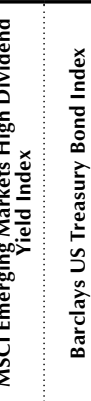 & 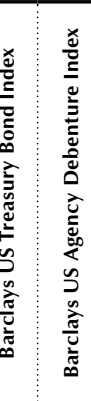 & 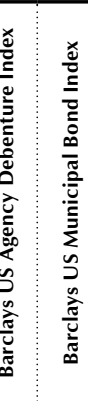 & 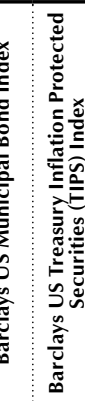 & 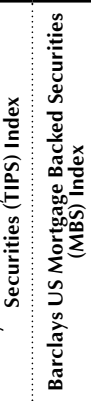 & 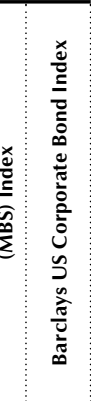 & 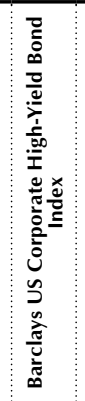 & 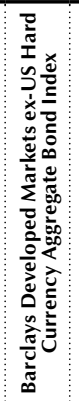 & 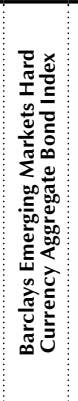 & 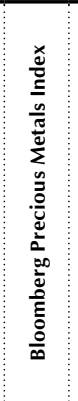 & 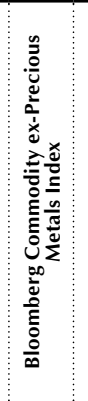 & 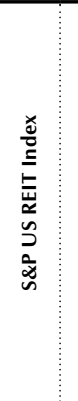 & 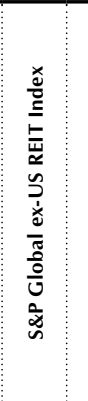 & 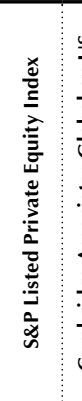 & 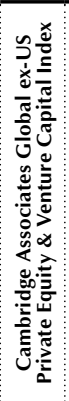 & 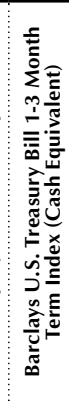 \\
\hline MSCI USA Index & 1,000 & & & & & & & & & & & & & & & & & & & & & & & \\
\hline MSCI USA Small Cap Index & 0,949 & 1,000 & & & & & & & & & & & & & & & & & & & & & & \\
\hline MSCI EAFE Index & 0,886 & 0,817 & 1,000 & & & & & & & & & & & & & & & & & & & & & \\
\hline MSCI EAFE Small Cap Index & 0,852 & 0,814 & 0,961 & 1,000 & & & & & & & & & & & & & & & & & & & & \\
\hline MSCI Emerging Markets Index & 0,813 & 0,804 & 0,866 & 0,8651 & 1,000 & & & & & & & & & & & & & & & & & & & \\
\hline MSCI Emerging Markets Small Cap Index & 0,779 & 0,775 & 0,842 & 0,8570 & 0,9651 & 1,000 & & & & & & & & & & & & & & & & & & \\
\hline MSCI USA High Dividend Yield Index & 0,903 & 0,849 & 0,791 & 0,748 & 0,7300 & $0,686: 1$, & 1,000 & & & & & & & & & & & & & & & & & \\
\hline MSCI EAFE High Dividend Yield Index & 0,847 & 0,746 & 0,967 & 0,9040 & 0,7990 & 0,7730 & $0,8141,0$ & 1,000 & & & & & & & & & & & & & & & & \\
\hline MSCI Emerging Markets High Dividend Yield Index & 0,795 & 0,778 & 0,869 & 0,8740 & 0,9880 & 0,9460 & $0,724 \quad 0,8$ & $0,806: 1,00$ & 000 & & & & & & & & & & & & & & & \\
\hline Barclays US Treasury Bond Index & 0,505 & $5,-573$ & $-0,419$ & 0,408 & $-0,357-0$ & $0,345-0$ & $-0,327-0$ & $0,335-0,3$ & 3091,0 & 000 & & & & & & & & & & & & & & \\
\hline Barclays US Agency Debenture Index & 0,140 & $-0,140$ & 0,095 & $-0,1830$ & 0,0380 & $0,038-0$ & $-0,062-0$ & $0,0300,0$ & 0340,1 & $40 \quad 1,00$ & & & & & & & & & & & & & & \\
\hline Barclays US Municipal Bond Index & $-0,209$ & 90,189 & 0,168 & $-0,153 \quad 0$ & 0,0220 & $0,057 \quad 0$ & $0,230-0$ & $0,153: 0,0$ & 0110,11 & 1040,67 & 5731,00 & & & & & & & & & & & & & \\
\hline Barclays US Treasury Inflation Protected Securities (TIPS) Index & $-0,028$ & 80,097 & 0,072 & 0,089 & 0,1870 & 0,1900 & $0,052 \quad 0,1$ & $0,110 \quad 0,2$ & 2120,6 & $652-0,0$ & 0200,0 & 411,0 & 000 & & & & & & & & & & & \\
\hline Barclays US Mortgage Backed Securities (MBS) Index & 0,195 & $-0,287$ & 0,086 & 0,071 & $0,002-0$ & 0,011 & $-0,047-0$ & $0,033: 0,0$ & 0460,7 & 7900,0 & 2510,0 & 350,7 & 7501,00 & & & & & & & & & & & \\
\hline Barclays US Corporate Bond Index & 0,159 & 0,075 & 0,307 & 0,292 & 0,3760 & 0,398 : & $0,274 \quad 0$, & $0,3310,3$ & 3970,5 & 5420,10 & 090,08 & 820,6 & 6800,63 & 331,000 & & & & & & & & & & \\
\hline Barclays US Corporate High-Yield Bond Index & 0,744 & 0,717 & 0,804 & 0,7730 & 0,8390 & $0,848: 0$, & $0,711: 0,7$ & $0,779: 0,8$ & $821-0,2$ & $248: 0,0$ & 020,02 & $27: 0,2$ & 2780,06 & 590,583 & 1,000 & & & & & & & & & \\
\hline Barclays Developed Markets ex-US Hard Currency Aggregate Bond Index & 0,166 & $-0,252$ & 0,025 & $-0,0080$ & 0,0150 & $0,053-0$ & $0,027: 0, \mathrm{C}$ & $0,0250,0$ & 0590,7 & 7040,12 & 290,1 & 500,5 & 5710,6 & 390,700 & 0,113 & 1,000 & & & & & & & & \\
\hline Barclays Emerging Markets Hard Currency Aggregate Bond Index & 0,501 & 0,433 & 0,578 & 0,5470 & 0,6940 & 0,6770 & $0,434 \quad 0$, & $0,5750,6$ & \begin{tabular}{c:cc}
$683-0$, \\
\hdashline
\end{tabular} & $, 0400,2$ & $260,0,2$ & 2990,3 & $310 \quad 0,17$ & 0,495 & 0,701 & 0,1521 & 1,000 & & & & & & & \\
\hline Bloomberg Precious Metals Index & 0,257 & 0,257 & 0,249 & 0,297 & 0,4120 & 0,3820 & 0,1610, & $0,2040,4$ & 4170,1 & $134-0,0$ & $078-0,1$ & 1100,47 & 4750,28 & 320,260 & 0,227 & 0,0950 & 0,400 & 1,000 & & & & & & \\
\hline Bloomberg Commodity ex-Precious Metals Index & 0,693 & 0,627 & 0,705 & 0,678 & 0,7020 & 0,6570 & $0,621 \quad 0,7$ & $0,7010,7$ & $713-0$, & $, 381-0,0$ & $074-0,2$ & 2170,0 & $028-0,1$ & 310,153 & 0,588 & $-0,222$ & 0,563 & 0,455 & 1,000 & & & & & \\
\hline S\&P US REIT Index & 0,764 & 0,753 & 0,724 & 0,688 & 0,6900 & 0,6660 & $0,7820,7$ & $0,7280,6$ & $687-0,1$ & $, 180-0,0$ & $067-0,1$ & 1630,2 & 2290,11 & 20,430 & 0,748 & 0,128 & 0,529 & 0,233 & 0,5161 & 1,000 & & & & \\
\hline S\&P Global ex-US REIT Index & 0,641 & 0,637 & 0,586 & 0,548 & 0,5560 & 0,5340 & 0,6940, & $0,601: 0,5$ & $552-0$, & $, 051-0,0$ & $060-0,1$ & 1560,2 & 2760,18 & 340,444 & 40,652 & 0,200 & 0,459 & 0,202 & 0,4080 & 0,9481 & 1,000 & & & \\
\hline S\&P Listed Private Equity Index & 0,908 & 0,906 & 0,912 & 0,911 & 0,8280 & 0,8010 & 0,8130 & $0,8470,8$ & $818-0$, & $434-0,1$ & $197-0,2$ & 2130,0 & $060-0,1$ & 100,258 & 0,792 & $-0,0810$ & 0,523 & 0,263 & 0,6190 & 0,7560 & $0,636: 1$, & 1,000 & & \\
\hline Cambridge Associates Global ex-US Private Equity \& Venture Capital Index & 0,470 & 0,450 & 0,511 & 0,512 & 0,4940 & 0,4850 & 0,3650 & $0,478: 0,4$ & $498-0$, & $414-0,0$ & $030-0,8$ & $042-0$, & $112-0,2$ & 020,010 & 0,387 & $-0,2010$ & 0,278 & 0,125 & 0,3930 & 0,285 & 0,0340, & 0,4601, & 1,000 & \\
\hline Barclays U.S. Treasury Bill 1-3 Month Term Index (Cash Equivalent) & 0,040 & $0=0,051$ & 0,018 & $3-0,033$ & $-0,086-1$ & $0,030=-1$ & $-0,0490$, & $0,036=0$, & $0,127-0$, & $, 087=0,0$ & $042=0$, & $018=0$, & $065-0,1$ & $41-0,161$ & $1=0,043$ & $-0,206$ & $-0,261$ & 0,131 & $0,090=0$ & $-0,102=-$ & $-0,163=0$ & $-0,093: 0$, & 0,171 & 1,000 \\
\hline
\end{tabular}

